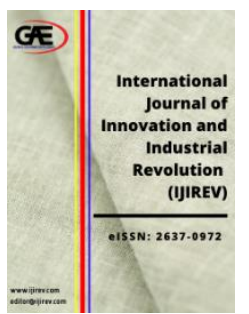

\author{
INTERNATIONAL JOURNAL OF \\ INNOVATION AND \\ INDUSTRIAL REVOLUTION \\ (IJIREV) \\ wWw.ijirev.com
}

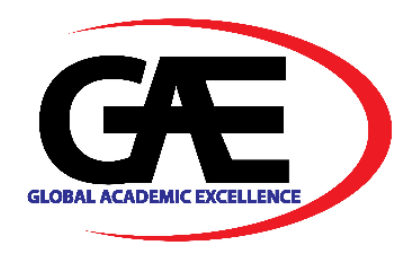

\title{
DYNAMIC SAFETY INTERACTIONS FOR IMPROVING QUALITY OF WORK LIFE: A PROPOSED CONCEPTUAL FRAMEWORK FOR ENGINEERS IN MANUFACTURING INDUSTRIES
}

\author{
Norizan Baba Rahim ${ }^{1}$ \\ 1 School of Distance Education, Universiti Sains Malaysia, Malaysia \\ Email: norizanbaba@usm.my
}

\section{Article Info:}

Article history:

Received date: 17.10 .2021

Revised date: 20.11 .2021

Accepted date: 31.11.2021

Published date: 05.12.2021

\section{To cite this document:}

Rahim, N. B. (2021). Dynamic Safety Interactions For Improving Quality Of Work Life: A Proposed Conceptual Framework For Engineers In Manufacturing Industries. International Journal of Innovation and Industrial Revolution, 3 (9), 0917.

DOI: $10.35631 /$ IJIREV.39002

This work is licensed under $\underline{\mathrm{CC} B Y} 4.0$

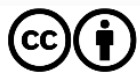

\begin{abstract}
:
In Malaysia's manufacturing industry, workplace accidents and injuries are a big problem. This industry has made only minor progress in terms of reducing fatalities and significant injuries. The fatal injury rate decreased marginally; however, the previous year's severe injury rate stayed unchanged. (Department of Occupational Safety and Health (DOSH), 2021). As a result, manufacturing safety continues to be a severe issue in Malaysia. The organisational nature of industrial accidents has been highlighted in safety literature, and empirical study has focused on determining the organisational, managerial, and environmental elements that influence accident causation. The majority of prior works have emphasised the concept of safety culture (or safety climate). Scholars have recently begun to look into additional organisational elements, such as the impact of organisational environment, leadership style, and occupational stressors on industrial accidents. This study presents a conceptual framework to investigate the interaction between safety climate and safety behaviour in Malaysia's manufacturing sector, with the goal of developing more effective safety interventions to reduce accidents.
\end{abstract}

Keywords:

Safety Climate, Safety Behaviour, Quality of Work-Life 


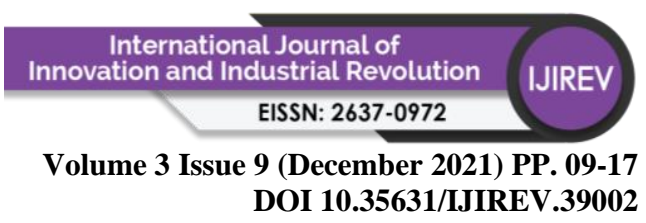

\section{Introduction}

Malaysia began its industrialisation effort in the 1960s with the vision of becoming an industrialised nation by 2020. The industrialisation has been a vital constituent of Malaysia's development strategies since it is part of a long-term goal of achieving the country's target to be a fully developed nation. This strategy requires large-scale investments, including new machinery, equipment, and technology (Said, Halim, \& Said, 2012).

As reported by Wan (2016) in the new suitability index, Malaysia is ranked as the world's top manufacturing site, and the country's manufacturing industry is an essential backbone and contributor to the economy. For example, Gross Domestic Product (GDP) contributed from the manufacturing sector demonstrates its importance to the economy, as reported by the Department of Statistics Malaysia (2021). Economic activity from manufacturing sector achieved the highest economic growth of 6.6 per cent, and it is among the five key sectors that contributed significantly to GDP from 2019 to 2021 (see Table 1).

Table 1: Annual Growth of Five Main Economic Activities

\begin{tabular}{|c|c|c|c|c|c|c|c|}
\hline \multirow{2}{*}{ Sectors } & \multirow[t]{2}{*}{2019} & \multirow[t]{2}{*}{2020} & \multicolumn{4}{|c|}{2020} & \multirow{2}{*}{$\begin{array}{c}2021 \\
\text { Q1 }\end{array}$} \\
\hline & & & Q1 & Q2 & Q3 & Q4 & \\
\hline Agriculture & 2.0 & -2.2 & -8.6 & 0.9 & -0.3 & -1.0 & 0.4 \\
\hline Mining \& Quarrying & -0.6 & -10.6 & -2.9 & -20.8 & -7.8 & -10.4 & -5.0 \\
\hline Manufacturing & 3.8 & -2.6 & 1.4 & -18.3 & 3.3 & 3.0 & 6.6 \\
\hline Construction & 0.4 & -19.4 & -7.9 & -44.5 & -12.4 & -13.9 & -10.4 \\
\hline Services & 6.2 & -5.5 & 3.1 & -16.2 & -4.0 & -4.8 & -2.3 \\
\hline
\end{tabular}

Source: Publication, Infographics, Pocket Statistics as of Q3 2018, Department of Statistics Malaysia

The Industrial Production Index (IPI) increased by 9.3 per cent in March 2021 compared to March 2020, based on current positive trend indicators in the manufacturing sector. The growth in March 2021 was supported by the increase in Manufacturing (12.7\%), Electricity $(10.3 \%$,) and Mining (-1.9\%) sectors (see Table 2).

Table 2: Industrial Production Index Malaysia March 2021

\begin{tabular}{cccc}
\hline Industrial Production Index (IPI) & Mining & Manufacturing & Electricity \\
\hline $9.3 \%$ & $-1.9 \%$ & $\mathbf{1 2 . 7 \%}$ & $10.3 \%$ \\
\hline
\end{tabular}

Source: Statistics, Time Series Data, Labor Force Survey (LFS), Department of Statistics Malaysia

Although industrialisation, predominantly the manufacturing sector, is beneficial to the country, it has some negative impacts, such as industrial accidents and occupational stress diseases. These incidents have caused a substantial economic loss, including loss of man-days and productivity and pain and suffering to those injured.

The statistics of accidents in Malaysia's manufacturing industry exposed that the accident rate in this industry remains high. It illustrates that existing site safety practices in the manufacturing industry require extensive and rapid overhaul. These ten sectors have seen Department of Occupational Safety and Health (DOSH) 1,948 occupational accidents since March 2021. The ten sectors are 1) restaurant and hotel, 2) utilities, including gas, electricity, water and sanitary service), 3) insurance, finance, real estate and business services, 4) construction, 5) storage, communication and transport, 6) manufacturing, 7) wholesale and 
Volume 3 Issue 9 (December 2021) PP. 09-17 DOI 10.35631/IJIREV.39002

retail trade, 8) public services and statutory authorities, 9) quarrying and mining, and 10) agriculture, forestry and fishery. Of the 1,948 accident cases, 42 were death cases, 1,831 were non-permanent disability cases, and 75 were permanent disability cases.

Amongst the ten sectors, the manufacturing sector had the most occupational accidents with 1,420 cases $(64 \%)$, with ten death, 1,172 non-permanent disability, and 58 permanent disability cases. Next, the agriculture, forestry, and fishing sectors have seen 265 cases (14\%), with no death cases, but recorded a devastating 262 non-permanent disability cases and three permanent disability cases. Finally, the third-highest number of occupational accidents belonged to the insurance, finance, real estate \& business services sector that observed 113 (65\%) cases, with five death cases, 102 non-permanent disability cases, and six permanent disability cases (see Table 3).

Table 3: Occupational Accidents Statistics by Sectors as of March 2021

\begin{tabular}{|c|c|c|c|c|c|}
\hline No & Sectors & $\begin{array}{l}\text { Non-Permanent } \\
\text { Disability }\end{array}$ & $\begin{array}{l}\text { Permanent } \\
\text { Disability }\end{array}$ & Death & Total \\
\hline 1. & Manufacturing & 1,172 & 58 & 10 & 1,240 \\
\hline 2. & $\begin{array}{l}\text { Agriculture, Forestry and } \\
\text { Fishing }\end{array}$ & 262 & 3 & 0 & 265 \\
\hline 3. & $\begin{array}{l}\text { Finance, Insurance, Real } \\
\text { Estate and Business } \\
\text { Services }\end{array}$ & 102 & 6 & 5 & 113 \\
\hline 4. & $\begin{array}{l}\text { Transport, Storage and } \\
\text { Communication }\end{array}$ & 68 & 1 & 2 & 71 \\
\hline 5. & $\begin{array}{l}\text { Wholesale and Retail } \\
\text { Traders }\end{array}$ & 64 & 1 & 0 & 65 \\
\hline 6. & Construction & 43 & 4 & 23 & 70 \\
\hline 7. & $\begin{array}{l}\text { Utility (Electricity, Gas, } \\
\text { Water and Sanitary } \\
\text { Services) }\end{array}$ & 43 & 0 & 0 & 43 \\
\hline 8. & Hotels and Restaurants & 40 & 1 & 0 & 41 \\
\hline 9. & $\begin{array}{l}\text { Public Services and } \\
\text { Statutory Bodies }\end{array}$ & 25 & 0 & 0 & 25 \\
\hline 10. & Mining and Quarrying & 12 & 1 & 2 & 15 \\
\hline & Total & $\mathbf{1 , 8 3 1}$ & 75 & 42 & 1,942 \\
\hline
\end{tabular}

Source: DOSH

Additionally, the manufacturing sector registered of the most occupational disease and poisoning incidents in 2020, with $82.3 \%$. This was followed by the utilities (electricity, gas, water \& sanitary service) sector with $9.1 \%$ and $2.4 \%$ from the mining \& quarrying sector (see Table 4). Hence, the manufacturing sector workers are more vulnerable to accidental risks. 
Volume 3 Issue 9 (December 2021) PP. 09-17 DOI 10.35631/IJIREV.39002

Table 4: Occupational Disease and Poisoning Statistics by Sectors as of March 2021

\begin{tabular}{clc}
\hline No. & \multicolumn{1}{c}{ Sectors } & Percentage \\
\hline 1. & Manufacturing & $82.3 \%$ \\
2. & Utilities & $9.1 \%$ \\
3. & Mining and Quarrying & $2.4 \%$ \\
4. & Finance, Insurance, Real Estate and Business Services & $1.4 \%$ \\
5. & Transport, Storage and Communication & $1.4 \%$ \\
6. & Public Services and Statutory Bodies & $1.3 \%$ \\
7. & Agriculture, Forestry and Fishing & $1.3 \%$ \\
8. & Hotels and Restaurants & $0.5 \%$ \\
9. & Construction & $0.3 \%$ \\
10. & Wholesale and Retail Traders & $0.3 \%$ \\
\hline \multicolumn{2}{r}{} \\
\hline
\end{tabular}

Source: DOSH

Since the risk of accident occurrence is high in the manufacturing industry, it is a high-risk industry. The natural hazard of the manufacturing sector is highly reactive to the business cycle, especially in mature capitalist economies (Said et al., 2012). The Malaysian manufacturing industry accident statistics reveal that this industry's accident rate is still high. This is because factors such as time, cost, and quality are considered ahead of safety (Hamid, Majid, \& Singh, 2008). In other words, safety issues take a back seat in the manufacturing sector. Thus, the manufacturing industry's current site safety practices require a quick and colossal overhaul.

\section{Purpose of the Study}

Engineers play a critical part in the progress of Malaysia's technical breakthroughs. For instance, the economic development in Malaysia is greatly contributed by engineers, as they are the main players in the field of manufacturing (Rahim, 2020). Besides, the use of appropriate technologies and processes is handled by them. Furthermore, they serve as a key to wealth generation and assist the country in becoming a global participant (Rahim, 2020). Engineers have substantially impacted the community, and every engineering project must be safe and beneficial to its users. Many scholars believe that circumstances that link both directly and indirectly to accidents exist (Forteza, Carretero-Gomez, \& Sese, 2017; Lu, Taksa, \& Jia, 2020). Poor well-being outcomes that have been connected to accidents, poor health, and safety could indicate a severe issue.

The extensive employment of new workers and new technology, machinery, and equipment is linked to the rapid growth of manufacturing industries during an economic upswing. The consequences of the use of new technologies make employees more likely to be exposed to risk. Similarly, new workers might encounter a higher risk of accidents because they are not familiar with the workplace environment hazard. The manufacturing industry is defined by a heavy emphasis on output. Operational safety is lowered as a result of high-performance pressures and time constraints. Engineers must meet stringent deadlines to complete their work. As a result, they may persuade workers to make concessions, putting their safety at risk. This has resulted in tasks such as developing and maintaining a safe work environment for employees being shouldered by manufacturing engineers. In a mature capitalist economy, the natural dangers of the manufacturing sector are highly responsive to business cycles (Proven et al., 2020). 


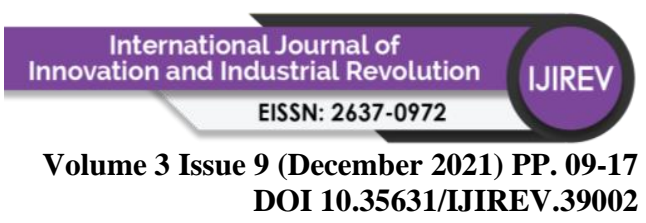

There is a constant need for safety in various engineering professions, and in some circumstances, engineers have legal responsibility for maintaining safety. A constant emphasis on the importance of safety in a hazardous setting could become a bigger source of stress than the threats themselves. Langdon and Sawang (2018) have reported that carrying excessive responsibility for other people's lives and safety is the main source of psychological stress. Furthermore, their research found that employment features are linked to ill-health, as engineers who work in physically demanding environments are more prone to illness.

As depicted in Table 3, the manufacturing industry has the highest rate of accidents. This scenario would result in financial loss and non-monetary losses, such as affecting the companies' reputation. Additionally, this scenario could worsen if limited research concerning engineers' well-being is conducted. Therefore, safety behaviours must be seriously addressed and promptly monitored at the workplace to prevent the rise in accident cases so that engineers can maintain excellent performance and increase their well-being.

In short, the individual well-being of engineers in the manufacturing sector is threatened. Therefore, a study of the association between the safety climate, safety behaviour, and the quality of work-life among professional engineers in Malaysian manufacturing industries is critical. As a result, these research issues will be tackled in this study:

1. To investigate the influence of safety climate on safety behaviour among professional engineers in Malaysian manufacturing industries.

2. To investigate the influence of safety behaviour on the quality of work-life among professional engineers in Malaysian manufacturing industries.

3. To investigate the mediating effect of safety behaviour on the relationship between safety climate and quality of work-life among professional engineers in Malaysian manufacturing industries.

\section{Proposed Conceptual Framework and Hypotheses}

The proposed conceptual framework for this research is illustrated in Figure 1 and consists of the independent variable (safety climate), dependent variable (quality of work-life), and mediating variable (safety behaviour).

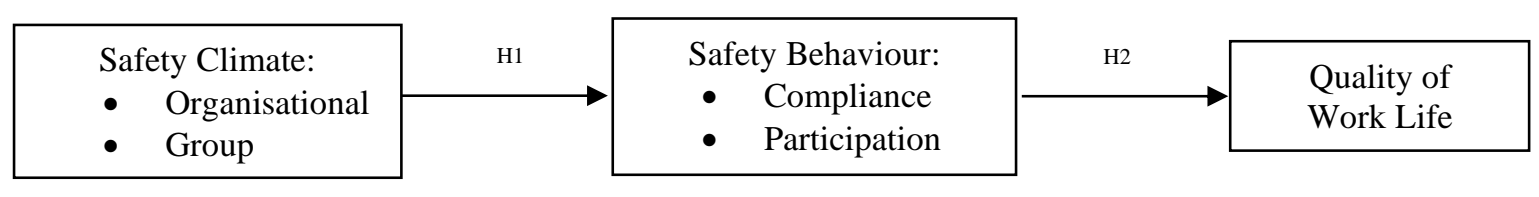

$\mathrm{H} 3$

Figure 1: The Proposed Conceptual Framework

Grounded on the framework, the subsequent hypotheses have been developed as follows:

According to Neal, Griffin \& Hart (2000), the increasing levels of safety climate will result in lower accident rates. Also, supported by Lyu et al. (2018), a safety climate can foster and promote safety behaviours. Therefore, this present investigation considers the positive findings 


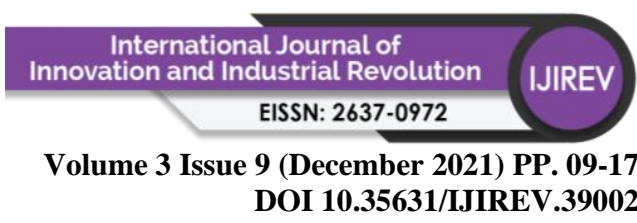

and expects that safety climate will positively influence safety behaviour. Thus, the following hypothesis is proposed:

H1: Safety climate has a significant relationship with safety behaviour.

The determinant of quality of work life is from a healthy and safe work environment (Pacheco \& Riaño-Casallas, 2017). In fact, wealth, productivity and protection of employees in the workplace are the goals of quality of life and safety as well as health in the workplace (Prodanova \& Kundurzhiev, 2018). Therefore, this study considers the positive findings and expects that safety behaviour positively influences the quality of working life. Thus, the following hypothesis is proposed:

H2: Safety behaviour has a significant relationship with quality of work life.

According to the reciprocal norms stated by $\mathrm{Hu}$ et al., (2021), employees who have safety behaviours will expand their formal roles if they feel that their environment is very important to their well-being and safety. At the same time, safety behaviours can enhance their quality of work life. Therefore, this study considers the positive findings and expects that safety behaviour mediates the relationship between safety climate and quality of working life. Thus, the following hypothesis is proposed:

\section{H3: Safety behaviour mediates the relationship between safety climate and quality of work} life.

\section{Methodology}

\section{Population and Sample Size}

This study used Hair, Black, Babin, and Anderson (2010)'s "10 times" rule of thumb to calculate the minimal sample size for real data collection. They proposed that the sample size must be no less than five times the number of variable items to be examined. Nonetheless, a 5:1 ratio, i.e. five respondents to one observed variable item, is a more acceptable way to determine the sample size. The total number of items to measure every variable was 48 in this current research. As such, the acceptable minimum sample size was 5 multiplied by 48, i.e. 240 respondents.

\section{Sampling Technique}

The purposive sampling method was used in this research. A specific type of person who can supply the needed information is picked in this strategy. They were chosen because they are the only ones with the necessary information or meet the study's criteria. (Sekaran \& Bougie, 2010). In this study, professional engineers that conform to the inclusion criterion as follows are chosen:

1. registered with the Board of Engineers Malaysia (BEM) as professional engineers;

2. accumulated at least 50 hours of Continuing Professional Development (CPD) activities in the year 2020; and

3. currently employed in manufacturing industries only. 


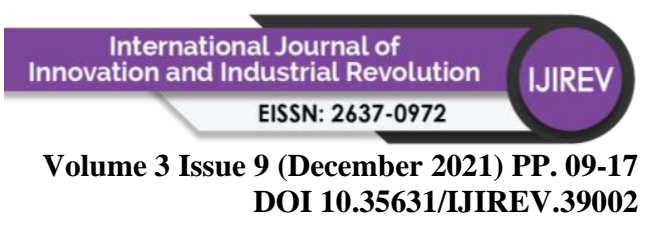

\section{Data Collection Procedure}

Self-administered questionnaires will be used for data collection. The respondents are professional engineers registered with BEM. They must participate in CPD activities since they must have accumulated at least 50 hours of CPD per year to renew their practising certificates. The questionnaires will be distributed and emailed according to the scheduled activities. These activities' schedule will be retrieved from the Institute of Engineers Malaysia (IEM)'s website. Before each CPD activity, the researcher will approach the venue management to explain the research objectives and seek permission for the placement of the questionnaires and email them throughout the activity. After permission is obtained, the time to distribute the questionnaires will be arranged.

\section{Instruments}

The measurement items used in this study are adopted from past investigations with acceptable reliabilities (Cronbach's alpha). Ratings will be based on a 5-point Likert-type scale (1 = strongly disagree; $5=$ strongly agree) for every measurement item. The measures adopted in this study are summarised in Table 5.

Table 5: Measures Adopted For This Research

\begin{tabular}{cllccl}
\hline Section & \multicolumn{1}{c}{ Variables } & \multicolumn{1}{c}{ Dimensions } & $\begin{array}{c}\text { No of } \\
\text { Items }\end{array}$ & $\begin{array}{c}\text { Cronbach's } \\
\text { Alpha }\end{array}$ & Sources \\
\hline A & Safety Climate & $\begin{array}{l}\text { Organisational Safety } \\
\text { Climate } \\
\text { Group Safety Climate }\end{array}$ & 16 & 0.80 & $\begin{array}{l}\text { Zohar and } \\
\text { Luria } \\
(2005)\end{array}$ \\
B & $\begin{array}{l}\text { Safety } \\
\text { Behaviour }\end{array}$ & $\begin{array}{l}\text { Safety Compliance } \\
\text { Safety Participation }\end{array}$ & 3 & 0.89 & $\begin{array}{l}\text { Neal and } \\
\text { Griffin }\end{array}$ \\
& Quality of Work Life & 3 & & \\
C & & 10 & 0.89 & $\begin{array}{l}\text { Sirgy et al. } \\
\text { (2001) }\end{array}$ \\
\hline
\end{tabular}

\section{Data Analysis}

In the first phase, the Statistical Package for Social Sciences (SPSS) version 25 will be utilised for data analysis. The data were examined using SPSS statistical analysis, and the coding, outliers, and normality were analysed. SPSS will also generate descriptive statistics to show the data's characteristics in a frequency distribution, maximum, minimum, mean, standard deviation, and variance. In the second phase, hypothesis testing will be done using Partial Least Squares (PLS) with SmartPLS 2.0 M3. Following the approach, a research model analysis based on PLS regression was carried out in two stages: (1) assessment of the measurement model and (2) assessment of the structural model. In the first stage, the validity and reliability of every measure in the model must be determined. The structural model was evaluated in the second stage by estimating the routes between the constructs, establishing their importance, and assessing the model's predictive strength.

\section{Conclusion}

The goal of this study is to give empirical data about the association between safety climate, safety behaviour, and work-life quality. This study will look at how people perceive the safety climate in terms of safety behaviour and work-life quality in Malaysia, where studies are 


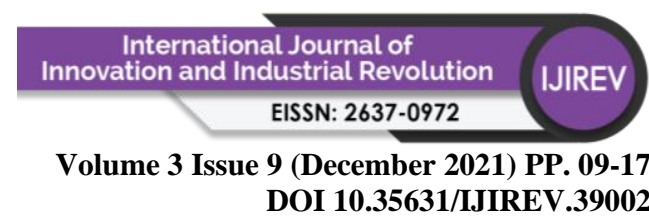

scarce. This study also suggests that safety behaviour in the Malaysian manufacturing industries can mediate the association between safety climate and work-life quality.

For practical contributions, this type of conceptual framework, if verified empirically, would benefit parties like the government and National Institute of Occupational Safety and Health (NIOSH), companies in the manufacturing industries, and researchers. For instance, the government, especially NIOSH, can enhance the safety and health standard of the workplace to raise the quality of human resources and overall national development. The success of human resources will speed up the attainment of national goals. Next, the manufacturing industries can enhance the worker's quality of life via the development of safety and health at the workplace. This framework could motivate workers to be more productive to raise company productivity, and work should be designed to provide engineers with power and control and give tasks that utilise their skills to raise satisfaction and decrease stress. Finally, researchers might be inspired to explore more and improve any company's safety and health issue besides suggesting that having job resource would lead to positive psychological outcomes. When more research is conducted, more solutions can be found.

\section{Acknowledgement}

This study did not receive any grant from any funding agency in the public, commercial, or not-for-profit sectors.

\section{References}

Forteza, F. J., Carretero-Gomez, J. M., \& Sese, A. (2017). Occupational risks, accidents on sites and economic performance of construction firms. Safety Science, 94, 61-76.

Hair, J. F., Anderson, R. E., Tatham. R. L., \& Black, W. L. (1992) Multivariate analysis with readings. New York, NY: MacMillan.

Hu, S. H., Wang, T., Ramalho, N. C., Zhou, D., Hu, X., \& Zhao, H. (2021). Relationship between patient safety culture and safety performance in nursing: The role of safety behaviour. International Journal of Nursing Practice, e12937.

Hamid, A. R. A., Majid, M. Z. A., \& Singh, B. (2008). Causes of accidents at construction sites. Malaysian Journal of Civil Engineering, 20(2), 242-259.

Langdon, R. R., \& Sawang, S. (2018). Construction workers' well-being: what leads to depression, anxiety, and stress? Journal of Construction Engineering and Management, 144(2), 04017100.

Lu, Y., Taksa, L., \& Jia, H. (2020). Influence of management practices on safety performance: The case of mining sector in China. Safety Science, 132, 104947.

Lyu, S., Hon, C. K., Chan, A. P., Wong, F. K., \& Javed, A. A. (2018). Relationships among safety climate, safety behavior, and safety outcomes for ethnic minority construction workers. International Journal of Environmental Research and Public Health, 15(3), 484.

Neal, A., \& Griffin, M. A. (2006). A study of the lagged relationships among safety climate, safety motivation, safety behavior, and accidents at the individual and group levels. Journal of applied psychology, 91(4), 946.

Neal, A., Griffin, M. A., \& Hart, P. M. (2000). The impact of organizational climate on safety climate and individual behaviour. Safety Science, 34(1-3), 99-109.

Pacheco, I. C. V., \& Riaño-Casallas, M. I. (2017). Contributions of occupational health and safety to the quality of working life: An analytical reflection. Ciencia y Tecnología para la Salud Visual y Ocular, 15(2), 85-94. 
Prodanova, Y. P., \& Kundurzhiev, T. G. (2018). Health And Safety At Work As Predictors Of Quality Of Working Life: Empirical Studies Among Workers In Medical Establishments. Eastern Academic Journal, 4, 207-214.

Proven, D. J., Woods, D. D., Dekker, S. W., \& Rae, A. J. (2020). Safety II professionals: How resilience engineering can transform safety practice. Reliability Engineering \& System Safety, 195, 106740.

Rahim, N. B. (2020). The Interaction between Protean Career Orientation, Career Goal Development and Well-Being Outcomes: Evidence from Professional Engineers. Gadjah Mada International Journal of Business, 22(1), 24-48.

Said, S. M., Halim, Z. A., \& Said, F. (2012). Workplace injuries in Malaysian manufacturing industries. Journal of Occupational Safety and Health, 9(1), 21-32.

Sekaran, U., \& Bougie, R. (2010). Research Methods for Small Business. A Skill Building Approach.

Sirgy, M. J., Efraty, D., Siegel, P., \& Lee, D. J. (2001). A new measure of quality of work life (QWL) based on need satisfaction and spillover theories. Social Indicators Research, 55(3), 241-302.

Wan, H. L. (2016). The Manufacturing Sector in Malaysia. In Organisational Justice and Citizenship Behaviour in Malaysia (pp. 21-36). Springer, Singapore.

Zohar, D., \& Luria, G. (2005). A multilevel model of safety climate: cross-level relationships between organisation and group-level climates. Journal of Applied Psychology, 90(4), 616. 